\title{
Nitric Oxide Production and Arachidonic Acid Metabolism in Platelet Membranes of Coronary Heart Disease Patients with and without Diabetes
}

\author{
Peteris Tretjakovs a,c Uldis Kalnins ${ }^{b}$ Inese Dabina ${ }^{a}$ Andrejs Erglis ${ }^{b}$ \\ Iveta Dinne ${ }^{b}$ Antra J urkaa,c Gustavs Latkovskis ${ }^{b}$ Agnis Zvaigzne ${ }^{a}$ \\ Valdis Pirags ${ }^{a}$ \\ aCentre of Endocrinology and bentre of Cardiology, P. Stradin's Clinical University Hospital, and \\ cInstitute of Experimental and Clinical Medicine, University of Latvia, Riga, Latvia
}

\section{Key Words}

Platelet · Nitric oxide · Arachidonic acid · Coronary artery disease - Diabetes

\begin{abstract}
Aim: To evaluate the levels of nitrite $\left(\mathrm{NO}_{2}^{-}\right)$and nitrate $\left(\mathrm{NO}_{3}^{-}\right)$ions and the incorporation of $\left[{ }^{3} \mathrm{H}\right]$ arachidonic acid (AA) into phospholipids of platelet membranes from coronary artery disease (CAD) patients with and without diabetes (NIDDM). Subjects and Methods: Eighteen CAD patients (group A), 18 CAD patients with NIDDM (group $B$ ), and 20 healthy controls (group C) without dyslipidemia, peripheral vascular disease and hypertension were included in the study. The groups were matched for age, sex and body mass index. The diagnosis of CAD was confirmed by coronary angiography. The nitric oxide end products (NOx), $\mathrm{NO}_{2}^{-}$plus $\mathrm{NO}_{3}^{-}$ions in platelet membranes, were determined using a spectrophotometric method based on the Griess reaction. The turnover of phospholipids was evaluated by incorporation of [ $\left.{ }^{3} \mathrm{H}\right] \mathrm{AA}$ into platelet membrane phospholipids. Results: A significantly smaller amount of NOx ions was in the platelet membrane of groups A (40 $\pm 8 \mu \mathrm{mol} / \mathrm{l})$ and B (29 \pm $10 \mu \mathrm{mol} / \mathrm{l})$ than $\mathrm{C}(57 \pm 6 \mu \mathrm{mol} / \mathrm{l}), \mathrm{p}<0.001$. Conversely a
\end{abstract}

\section{KARGER}

Fax +41613061234

E-Mail karger@karger.ch

www.karger.com

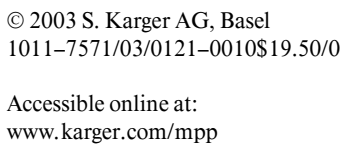

significantly greater amount of [ $\left.{ }^{3} \mathrm{H}\right] \mathrm{AA}$ was incorporated into platelet phospholipids of group $B$ patients $(5,123 \pm$ $1,637 \mathrm{dpm} / \mathrm{mg})$ than groups $A(3,159 \pm 1,253 \mathrm{dpm} / \mathrm{mg}$; $\mathrm{p}<0.002)$ and $C(1,621 \pm 417 \mathrm{dpm} / \mathrm{mg})$. An inverse correlation between [ $\left.{ }^{3} \mathrm{H}\right] \mathrm{AA}$ incorporation and NOx levels was established: $r=-0.76(p<0.05, n=36)$ in CAD patients. Conclusions: Diabetes in CAD patients decreased the ability to produce platelet-derived NO and affects AA metabolism. This may result in higher platelet sensitivity to aggregating stimuli.

Copyright $\odot 2003$ S. Karger AG, Basel

\section{Introduction}

The process of atherogenesis relates to platelet adherence and aggregation to the luminal surface, with the subsequent release of platelet-derived growth factors and vasoactive substances. An increased platelet-vessel wall interaction plays an important role in most forms of cardiovascular disease. Platelet activation involves multiple mechanisms for achieving activation, and the process of thrombosis involves multicellular modulation of platelet activity [1]. Several mediators, including thromboxane $\mathrm{A}_{2}\left(\mathrm{TXA}_{2}\right)$, serotonin, adenosine diphosphate, platelet-activating fac- 
Table 1. Clinical characteristics of study groups

\begin{tabular}{lccc}
\hline & \multicolumn{2}{l}{ CAD patients } & $\begin{array}{l}\text { Control } \\
\text { subjects } \\
\text { (group C) }\end{array}$ \\
\cline { 2 - 3 } & $\begin{array}{l}\text { without diabetes } \\
\text { (group A) }\end{array}$ & $\begin{array}{l}\text { with diabetes } \\
\text { (group B) }\end{array}$ & $20(9 / 11)$ \\
\hline $\mathrm{n}(\mathrm{M} / \mathrm{F})$ & $18(9 / 9)$ & $18(10 / 8)$ & $49 \pm 12$ \\
Age, years & $51 \pm 10$ & $52 \pm 9$ & $26.1 \pm 1.7$ \\
Body mass index, $\mathrm{kg} / \mathrm{m}^{2}$ & $26.8 \pm 1.3$ & $27.1 \pm 1.0$ & 5 \\
Smokers, $\mathrm{n}$ & 4 & 3 & $5.2 \pm 0.5$ \\
Total cholesterol, $\mathrm{mmol} / \mathrm{l}$ & $5.3 \pm 0.6$ & $5.5 \pm 0.9$ & $1.3 \pm 0.2$ \\
HDL cholesterol, mmol/1 & $1.3 \pm 0.4$ & $1.4 \pm 0.3$ & $3.0 \pm 0.7$ \\
LDL cholesterol, $\mathrm{mmol} / 1$ & $3.3 \pm 0.8$ & $3.4 \pm 0.9$ & $1.2 \pm 0.4$ \\
Triglyceride, mmol/1 & $1.2 \pm 0.9$ & $1.3 \pm 0.8$ & $3.8 \pm 0.6$ \\
HbA $\mathrm{Ic}, \%$ & $4.7 \pm 1.1$ & $6.4 \pm 1.0 *$ & $126 \pm 10 / 80 \pm 7$ \\
Arm blood pressure, $\mathrm{mm} \mathrm{Hg}$ & $127 \pm 10 / 81 \pm 8$ & $132 \pm 9 / 82 \pm 7$ & \\
\hline
\end{tabular}

$\mathrm{M}=$ Male; $\mathrm{F}=$ female. Results are expressed as number $(\mathrm{n})$, or mean $\pm \mathrm{SD} .{ }^{*} \mathrm{p}<0.001$ compared to the controls.

tor, oxygen-derived free radicals, activated thrombin, and tissue factor, promote platelet aggregation and vasoconstriction. At the sites of endothelial injury, there is reduction in absolute or relative amounts of endogenous inhibitors of platelet aggregation, including nitric oxide (NO), prostacyclin, and tissue plasminogen activator. Loss of the effects of endogenous inhibitors preventing platelet aggregation and vasoconstriction promotes a prothrombotic and vasoconstrictive environment [2].

Studies have revealed that not only endotheliumderived NO but also platelet-derived NO inhibits aggregation [3, 4]. Platelet-derived NO is involved in the control of platelet aggregability via cyclic $3^{\prime}, 5^{\prime}$-guanosine monophosphate (cGMP) synthesis and activates cGMP-dependent protein kinase, leading to inhibition of aggregation agonists, including $\mathrm{TXA}_{2}$ [5]. NO is also involved in regulating cyclooxygenase, where $\mathrm{TXA}_{2}$ is a major product of arachidonic acid (AA) conversion [6, 7]. Therefore, NO can be a potent inhibitor of cyclooxygenase activities in platelets [8].

Cardiovascular risk factors such as diabetes, dyslipidemia and hypertension are associated with increased platelet activation and decreased antithrombotic properties of the blood vessel wall [9]. Decreased constitutive endothelium-derived NO synthase activity and subsequent impaired activation by $\mathrm{NO}$ of soluble guanylate cyclase occur in diabetic patients and most likely contribute to the development of cardiovascular complications [10]. We had previously reported that dyslipidemia was associated with decreased platelet-derived NO production in coronary artery disease (CAD) patients without diabetes or hypertension [11] and that diabetes might induce platelet hyperreagibility via increased protein kinase $C_{\beta 1}$ activity [12]. The results of the experimental investigation in glomeruli of streptozocin-diabetic rats indicated a progressive impairment of NO-dependent cGMP generation, which might be mediated in part by $\mathrm{TXA}_{2}$ and activation of protein kinase C [13]. Therefore, we hypothesized that similar mechanisms might also be present in diabetic human platelets. Besides, platelet aggregation in diabetic patients increased despite good glycemic control [14].

This study was undertaken to assess changes in NO synthase activity and AA metabolism in platelet membranes of CAD patients with diabetes mellitus, but without dyslipidemia or hypertension.

\section{Subjects and Methods}

\section{Subjects}

Thirty-six patients with CAD, aged 40-70, were divided into two equal groups: group A (18 patients) had CAD alone and group B (18 patients) had CAD with type 2 diabetes mellitus (NIDDM). Twenty healthy subjects without CAD and NIDDM served as control (group C). The diagnosis of CAD was defined as exertion angina stable for at least 3 previous months. History of myocardial infarction or unstable angina was not an exclusion criterion unless an event had taken place within the previous 3 months. The diagnosis of CAD was confirmed by coronary angiography (performed on GE Medical System) and defined as $50 \%$ stenosis in at least one of the three major coronary arteries. CAD patients with any previous interventional treatment were excluded. 
Fig. 1. Incorporation of $\left[{ }^{3} \mathrm{H}\right] \mathrm{AA}$ into platelet membrane phospholipids of CAD patients $(n=36)$ and controls $(C ; n=20)$. Values are means $\pm \mathrm{SD}$.

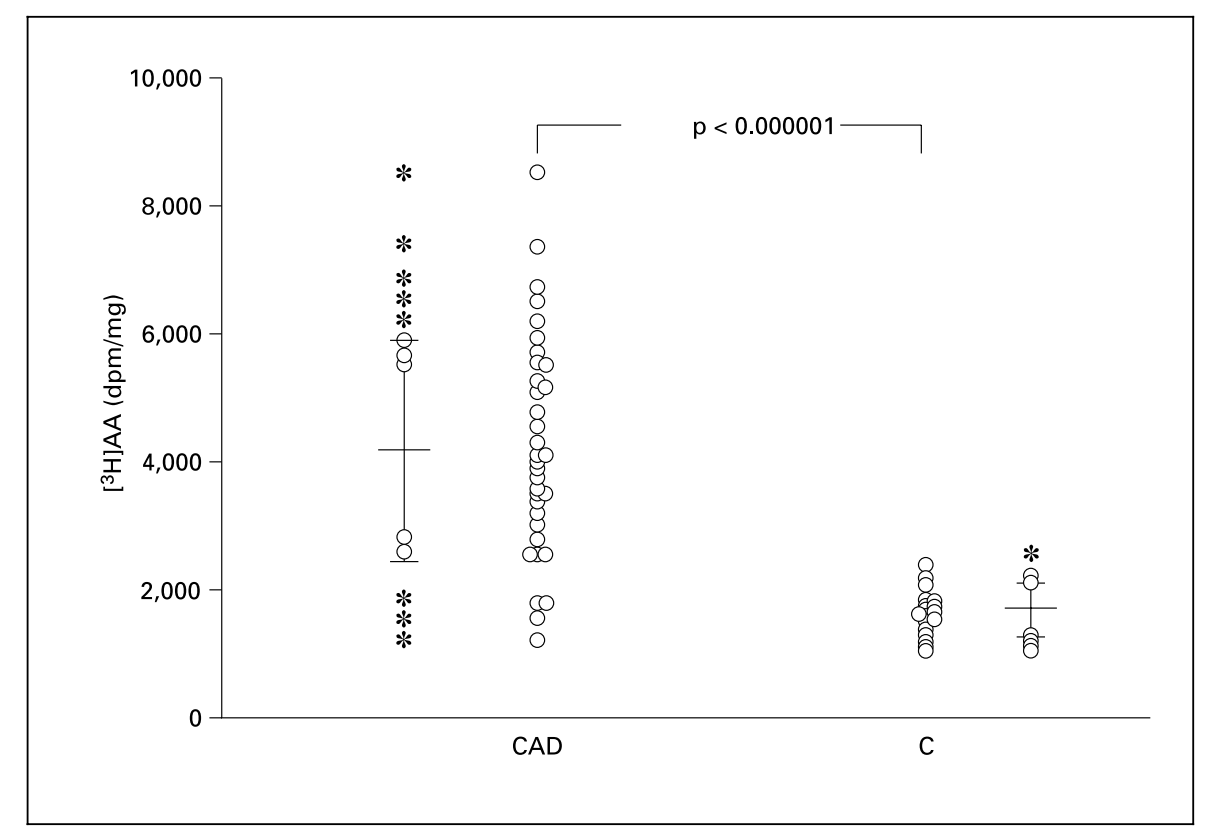

Clinically stable diabetics with good or satisfactory glycemic control (glycated hemoglobin $\mathrm{HbA}_{\mathrm{Ic}}<7.5 \%$ ) without proteinuria or other late stages of diabetic complications were included. Exclusion criteria for all subjects were dyslipidemia, any lipid lowering therapy within the previous 6 weeks, concomitant disorder affecting lipid levels, stroke, peripheral artery disease, venous insufficiency, pulmonary disease, anemia, hypertension, or malignancy. The groups were matched for age, sex, and body mass index (table 1). Informed consent was obtained from all subjects and the protocol was approved by the ethics committee.

\section{Procedures}

Twenty milliliters of venous blood was obtained from each subject after an overnight fast and abstinence from cigarette smoking for at least $12 \mathrm{~h}$. The blood was centrifuged at $360 \mathrm{~g}$ for $10 \mathrm{~min}$ at $4{ }^{\circ} \mathrm{C}$ (Hermle Z323H, Germany). Platelet-rich plasma was aspirated into a tube and centrifuged at $800 \mathrm{~g}$ for $10 \mathrm{~min}$, at $4^{\circ} \mathrm{C}$. Platelets were separated and purity was checked my microscopy of stained platelets. The average number of platelets in the sample was $2.2 \times 10^{9}$. Samples of platelets were lysed by sonication, in the presence of homogenization buffer (ultrasound homogenizer B, Braun Labsonic, Germany). To remove cytosolic cell extracts, samples were prepared by ultracentrifugation at $100,000 \mathrm{~g}$ for $50 \mathrm{~min}$ at $4^{\circ} \mathrm{C}$. Membrane cell extracts were prepared by processing the remaining platelet mass with sonication as previously described, and by using ultracentrifugation at $100,000 \mathrm{~g}$ for $10 \mathrm{~min}$ at $4^{\circ} \mathrm{C}$. The amount of protein in samples was determined by the Bradford method, which is based on a color change in response to various concentrations of proteins (Novaspec II, Pharmacia Biotech, UK). The protein concentration (mean $\pm \mathrm{SD}$ ) was $3.2 \pm 0.5 \mathrm{mg} / \mathrm{ml}$.

To assess NO synthase activity, the level of NO end products nitrite $\left(\mathrm{NO}_{2}^{-}\right)$plus nitrate $\left(\mathrm{NO}_{3}^{-}\right)$- in platelet membranes was determined using a spectrophotometric method based on the Griess reaction $[15,16]$. Briefly $\mathrm{NO}$ was oxidized to stable compounds of $\mathrm{NO}_{2}^{-}$ and $\mathrm{NO}_{3}^{-}, \mathrm{NO}_{3}^{-}$was converted to $\mathrm{NO}_{2}^{-}$and the amount of $\mathrm{NO}_{2}^{-}$was measured. In this way, the total amount of $\mathrm{NO}_{2}^{-}$plus $\mathrm{NO}_{3}^{-}$in the sample was measured. Freshly activated cadmium granules (2-2.5 g) were added to $1 \mathrm{ml}$ of pretreated deproteinized samples. After continuous stirring for $10 \mathrm{~min}$, the samples were transferred to appropriate tubes for $\mathrm{NO}_{2}^{-}$determination with Griess reagents [ $1 \%$ sulfanilamide, $5 \% \mathrm{H}_{3} \mathrm{PO}_{4}$, and $0.1 \% \mathrm{~N}-(1$-naphthyl)-ethylenediamine]. A standard curve using defined $\mathrm{NO}_{2}^{-}$standard samples $(0-100 \mu M)$ diluted in deionized distilled water was generated. Absorbance was measured at $550 \mathrm{~nm}[17,18]$.

To assess changes in AA metabolism, the incorporation of [ $\left.{ }^{3} \mathrm{H}\right] \mathrm{AA}$ into platelet membrane phospholipids [19], predominantly into phosphatidylcholine [20], was evaluated. Platelets were labeled with $0.5 \mu \mathrm{Ci} / \mathrm{ml}\left[{ }^{3} \mathrm{H}\right] \mathrm{AA}$ for $30 \mathrm{~min}$ at $37^{\circ} \mathrm{C}$ in phosphate buffer $(\mathrm{pH}$ 6.5). Platelet phospholipid was extracted by the method of Niwa et al. $[21,22]$. Radioactivity was measured by liquid scintillation counting and expressed as disintegrations per minute per milligram platelet protein. Glycated hemoglobin $\mathrm{HbA}_{\mathrm{Ic}}$ was determined and other clinical and biochemical analyses, including plasma concentrations of total cholesterol, triglyceride, and high-density lipoprotein (HDL) cholesterol, were performed by means of commercial enzymatic assays. Low-density lipoproteins (LDL) cholesterol was determined indirectly according to the formula of Friedewald et al. [23].

\section{Statistics}

Data were expressed as means \pm SD. Differences among groups were analyzed using the Mann-Whitney U test. Regression analysis was performed to evaluate the independent relations between parameters. A value of two-tailed $p<0.05$ was considered statistically significant. 
Fig. 2. Incorporation of $\left[{ }^{3} \mathrm{H}\right] \mathrm{AA}$ into platelet membrane phospholipids of CAD patients $(\mathrm{A} ; \mathrm{n}=18)$, CAD patients with diabetes $(\mathrm{B}$; $\mathrm{n}=18)$, and controls $(\mathrm{C} ; \mathrm{n}=20) .{ }^{\mathrm{a}} \mathrm{p}<0.001$ (vs. C); ${ }^{b} \mathrm{p}<0.00001$ (vs. C).

Fig. 3. $\mathrm{NO}$ end products $\left(\mathrm{NO}_{2}^{-}\right.$plus $\left.\mathrm{NO}_{3}^{-}\right)$in platelet membranes of CAD patients $(n=36)$ and controls $(C ; n=20)$. Values are means \pm SD.
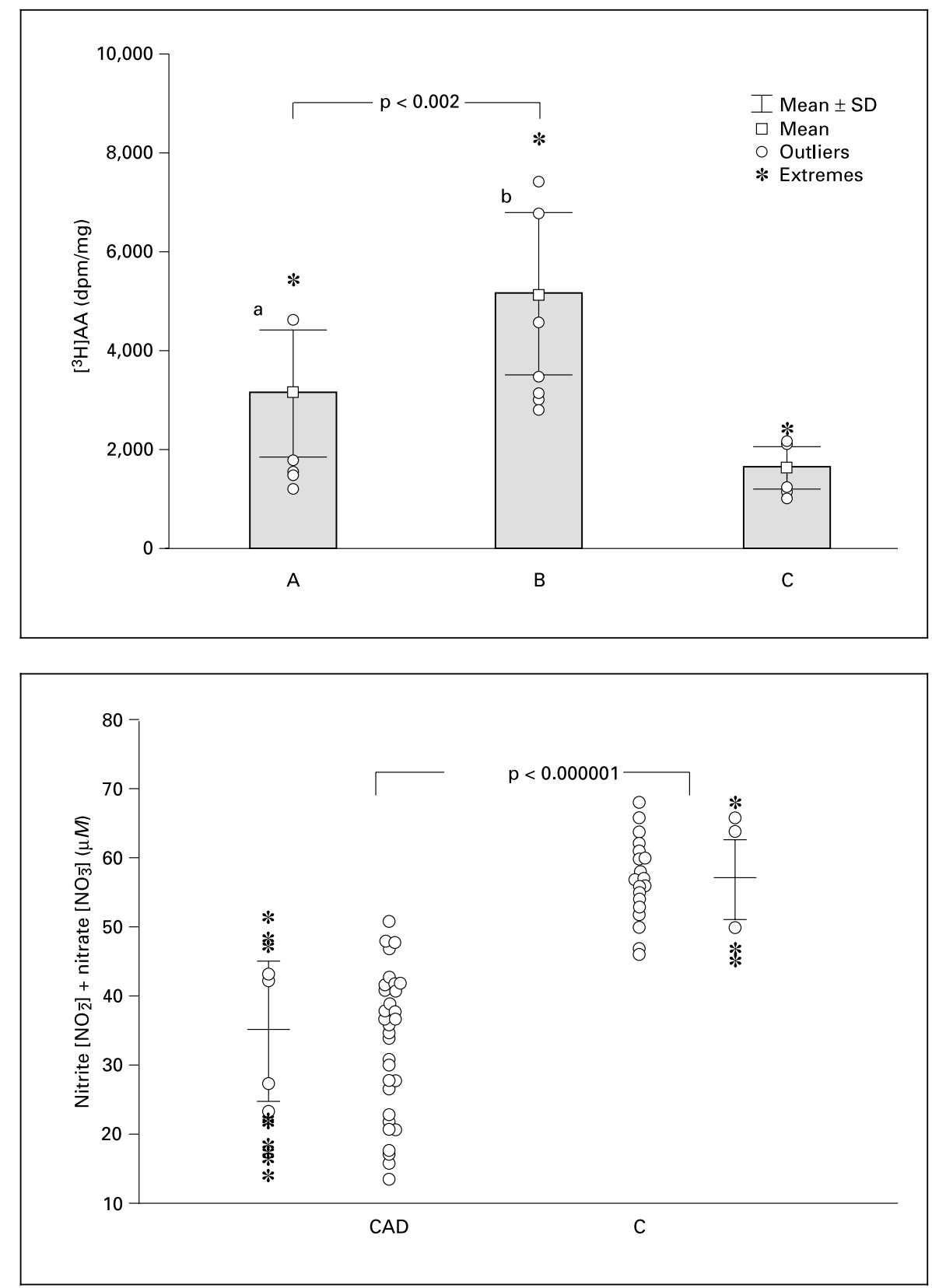

\section{Results}

A significantly greater amount of $\left[{ }^{3} \mathrm{H}\right] \mathrm{AA}$ was incorporated into platelet membrane phospholipids of all CAD patients $(4,083 \pm 1,737 \mathrm{dpm} / \mathrm{mg})$ than healthy subjects $(1,621 \pm 417 \mathrm{dpm} / \mathrm{mg}, \mathrm{p}<0.000001)$ (fig. 1). A significantly greater amount of $\left[{ }^{3} \mathrm{H}\right] \mathrm{AA}$ was incorporated in the platelet membrane phospholipids of NIDDM patients than in patients with CAD alone $(5,123 \pm 1,637 \mathrm{dpm} / \mathrm{mg})$ or in normal controls $(3,159 \pm 1,253 \mathrm{dpm} / \mathrm{mg}, \mathrm{p}<0.002)$ (fig. 2). All CAD patients had a significantly smaller amount of NO end products $(35 \pm 10 \mu \mathrm{mol} / \mathrm{l})$ in platelet membranes than healthy subjects $(57 \pm 6 \mu \mathrm{mol} / \mathrm{l}, \mathrm{p}<$ 0.0001) (fig. 3). The amount of $\mathrm{NO}$ end products in CAD patients alone $(29 \pm 10 \mu \mathrm{mol} / \mathrm{l})$ was smaller than that of CAD patients with NIDDM ( $40 \pm 8 \mu \mathrm{mol} / 1)$. The difference was statistically significant, $\mathrm{p}<0.001$ (fig. 4).

An inverse correlation between $\left[{ }^{3} \mathrm{H}\right] \mathrm{AA}$ incorporation and $\mathrm{NO}$ end product concentration in platelet membranes was: $\mathrm{r}=-0.76(\mathrm{p}<0.05, \mathrm{n}=36)$ in CAD patients (fig. 5). 
Fig. 4. $\mathrm{NO}$ end products $\left(\mathrm{NO}_{2}^{-}\right.$plus $\left.\mathrm{NO}_{3}^{-}\right)$in platelet membranes of CAD patients $(\mathrm{A} ; \mathrm{n}=$ 18), CAD patients with diabetes $(\mathrm{B} ; \mathrm{n}=18)$, and controls $(C ; n=20) .{ }^{a} \mathrm{p}<0.001$ (vs. $C$ ); ${ }^{\mathrm{b}} \mathrm{p}<0.00001$ (vs. C).

Fig. 5. Correlation between the $\mathrm{NO}$ end products $\left(\mathrm{NO}_{2}^{-}\right.$plus $\left.\mathrm{NO}_{3}^{-}\right)$in platelet membranes and the incorporation of $\left[{ }^{3} \mathrm{H}\right] \mathrm{AA}$ into platelet membrane phospholipids of CAD patients: $\mathrm{r}=-0.76(\mathrm{p}<0.05, \mathrm{n}=36)$.
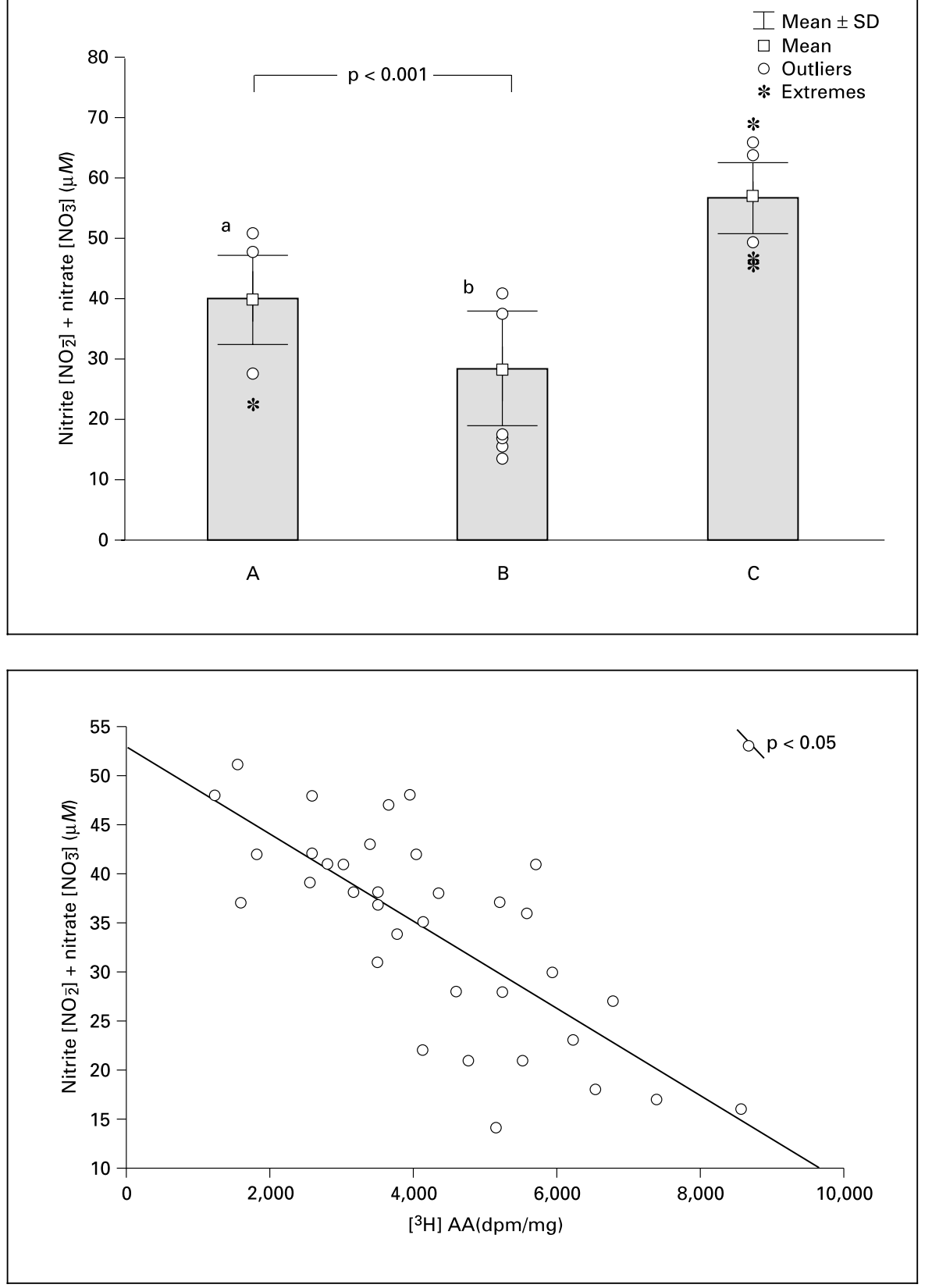

\section{Discussion}

Data obtained in this study indicate that significant differences exist in AA metabolism and NO production in platelet membranes between CAD patients and healthy subjects. The data show that there is a greater amount of $\mathrm{AA}$ incorporation and smaller amount of $\mathrm{NO}$ production in platelet membranes in CAD patients with diabetes mellitus than nondiabetic CAD patients or healthy subjects by indicating an inverse relationship between AA metabolism and NO production in the platelet membranes.

Recent studies have revealed that platelet-derived NO autoregulates platelet aggregation [3, 4]. There is evidence suggesting that $\mathrm{NO}$ has an influence on AA metabolism. $\mathrm{NO}$ can be a potent inhibitor of the cyclooxygenase activities [8] and may contribute to a decrease of $\mathrm{TXA}_{2}$ production [24]. It is known that platelet NO stimulates production of cGMP and activates cGMP-dependent protein 
kinase ( $\mathrm{G}$ kinase), leading to inhibition of Galphaq-phospholipase C-inositol 1,4,5-triphosphate signalling and intracellular calcium mobilization for several important agonists, including $\mathrm{TXA}_{2}$ [5].

There are other mechanisms of NO influence. NO exerts effects on thrombin receptor-activating, peptideinduced platelet aggregation and the surface expression of platelet activation markers [25]. Besides, NO-generating agents may inhibit P-selectin upregulation by lysophosphatidylcholine, an atherogenic lysophospholipid in oxidatively modified low-density lipoprotein (oxLDL) [26]. Evidence suggests that NO increases platelet sensitivity to the antiaggregating effects of substances acting via cGMP (insulin), and via cyclic adenosine-monophosphate (prostacyclin) $[27,28]$. These mechanisms are impaired in atherosclerotic patients [29].

In the heart, all cell types are affected by diabetes: the myocyte, the vasculature and the blood cells. Hyperglycemia causes significant protein alterations and an oxidative stress [30]. It is well established that platelet production of $\mathrm{TXA}_{2}$ and prostaglandin $\mathrm{E}_{2}$ are increased in diabetic patients [31]. A positive linear relationship was found between $\mathrm{HbA}_{\mathrm{Ic}}$ and $\mathrm{TXB}_{2}$ (a more stable form of $\mathrm{TXA}_{2}$ ) production. The results indicate that metabolic alterations can affect platelet function independently of vascular complications. The presence of increased $\mathrm{TXB}_{2}$ and prostaglandin $\mathrm{E}_{2}$ production from endogenous $\mathrm{AA}$ suggests that the activation of cyclooxygenase is not the only possible mechanism of platelet activation and that probably an increased availability of platelet AA plays an important role in the enhanced platelet aggregation commonly found in diabetics [31].
Platelets of diabetics and CAD patients with or without diabetes have greater sensitivity to aggregation, which might be due to the increased thromboxane synthetase system activity independently of total cholesterol or platelet phospholipid fatty acid distribution [32]. It might be possible that CAD patients with diabetes have elevated oxLDL in platelets as a result of oxidative stress induced by hyperglycemia [33]. Evidence also exists that oxLDL stimulates platelet function primarily by diminishing NO synthase expression, and this effect of oxLDL can be blocked by HDL [34]. It is known that production of $\mathrm{TXB}_{2}$ by platelets increases in patients with hypercholesterolemia [35] and oxLDL reduces the response of soluble guanylyl cyclase to nitrovasodilators [36]. oxLDL leads to impairment of calcium transport, resulting in activation of phospholipids, and, consequently, enhances formation of AA. An increased concentration of lipid peroxides may shift the prostaglandin synthesis from prostacyclin to thromboxane, causing enhanced platelet aggregability [37].

\section{Conclusion}

CAD patients have significantly altered AA metabolism, which is associated with reduced NO production in platelet membranes. These findings are consistent with the concept that NO is involved in the regulation of antiaggregating activities in multiple ways. Our results suggest that diabetes in CAD patients decreases the ability to produce platelet-derived NO and affects AA metabolism. This may result in higher platelet sensitivity to aggregating stimuli.

\section{References}

1 Rao GH, Rao AT: Pharmacology of platelet activation-inhibitory drugs. Indian $\mathbf{J}$ Physiol Pharmacol 1994;38:69-84.

2 Willerson JT: Conversion from chronic to acute coronary heart disease syndromes: Role of platelets and platelet products. Tex Heart Inst J 1995;22:13-19.

3 Tsao PS, Theilmeier G, Singer AH, Leung LL, Cooke JP: $L$-Arginine attenuates platelet reactivity in hypercholesterolemic rabbits. Arterioscler Thromb 1994;14:1529-1533.

4 Anfossi G, Russo I, Massucco P, Mattiello L, Perna P, Tassone F, Trovati M: L-Arginine modulates aggregation and intracellular cyclic 3,5-guanosine monophosphate levels in human platelets: Direct effect and interplay with antioxidative thiol agent. Thromb Res 1999;94: 307-316.
5 Wang GR, Zhu Y, Halushka PV, Lincoln TM, Mendelsohn ME: Mechanism of platelet inhibition by nitric oxide: In vivo phosphorylation of thromboxane receptor by cyclic GMP-dependent protein kinase. Proc Natl Acad Sci USA 1998;95:4888-4893.

6 Salvemini D: Regulation of cyclooxygenase enzymes by nitric oxide. Cell Mol Life Sci 1997; 53:576-582.

7 Tsikas D, Ikic M, Tewes KS, Raida M, Frolich JC: Inhibition of platelet aggregation by $\mathrm{S}$ nitroso-cysteine via cGMP-independent mechanisms: Evidence of inhibition of thromboxane A2 synthesis in human blood platelets. FEBS Lett 1999;442:162-166.
8 Fujimoto Y, Tagano S, Ogawa K, Sakuma S, Fujita T: Comparison of the effects of nitric oxide and peroxynitrite on the 12-lipoxygenase and cyclooxygenase metabolism of arachidonic acid in rabbit platelets. Prostaglandins Leukot Essent Fatty Acids 1998;59:95-100.

9 Luscher TF, Pfisterer M: Thrombocyte inhibitors in cardiovascular therapy. Schweiz Rundsch Med Prax 1990;79:1132-1141.

10 Lyons D: Impairment and restoration of nitric oxide-dependent vasodilation in cardiovascular disease. Int J Cardiol 1997;62:S101-S109.

11 Tretjakovs P, Kalnins U, Dabina I, Dinne I, Erglis A, Kumsars I, Jurka A: Plasma HDLcholesterol has an effect on nitric oxide production and arachidonic acid metabolism in the platelet membranes of coronary heart disease patients without LDL-hypercholesterolemia. Med Sci Monit 2000;6:507-511. 
12 Zvaigzne A, Bumbure A, Tretjakovs P, Lejnieks A, Pirags V: Regulation of synthesis and activity of protein kinase C- $\beta 1$ in platelets of diabetic patients after in vitro incubation; in Heilmeyer L, Friedrich P (eds): Protein Modules in Cellular Signalling. IOS Press, NATO Science Series A (Life Sciences), 2001, vol 318, pp 81-88.

13 Craven PA, Studer RK, DeRubertis FR: Impaired nitric oxide-dependent cyclic guanosine monophosphate generation in glomeruli from diabetic rats: Evidence for protein kinase Cmediated suppression of the cholinergic response. J Clin Invest 1994;93:311-320.

14 Kajita K, Ishizuka T, Miura A, Kanoh Y, Ishizawa $\mathbf{M}$, Kimura $\mathrm{M}$, Yasuda $\mathrm{K}$ : Increased platelet aggregation in diabetic patients with microangiopathy despite good glycemic control. Platelets 2001;12:343-351.

15 Green LC, Wagner DA, Glogowski J, Skipper PL, Wishnok JS, Tannenbaum SR: Analysis of nitrate, nitrite, and $\left[{ }^{15} \mathrm{~N}\right]$ nitrate in biological fluids. Anal Biochem 1982;126:131-138.

16 Marzinzig M, Nussler AK, Stadler J, Marzinzig E, Barthlen W, Nussler NC, Berger HG, Morris SM, Bruckner UB: Improved methods to measure end products of nitric oxide in biological fluids: Nitrite, nitrate, and S-nitrosothiols. Nitric Oxide 1997;1:177-189.

17 Moshage H: Nitric oxide determinations: Much ado about NO.-thing? Clin Chem 1997; 43:553-556.

18 Navarro-Gonzalvez JA, Garcia-Benayas C, Arenas J: Semiautomated measurement of nitrate in biological fluids. Clin Chem 1998;44:679681.

19 Neufeld EJ, Wilson DB, Sprecher H, Majerus PW: High affinity esterification of eicosanoid precursor fatty acids by platelets. J Clin Invest 1983;72:214-220.

20 Takahashi R, Morita I, Saito Y, Ito H, Murota $\mathrm{S}$ : Increased arachidonic acid incorporation into platelet phospholipids in type 2 (non-insulin-dependent) diabetes. Diabetologia 1984;26: 134-137.
21 Niwa Y, Sakane T, Tangichi S: Phospholipid transmethylation in the membrane of human neutrophils and lymphocytes. Arch Biochem Biophys 1984;234:7-14.

22 Neufeld EJ, Marjerus PW: Arachidonate release and phosphotidic acid turnover in stimulated human platelets. J Biol Chem 1983;258: 2461-2467.

23 Friedewald WT, Levy RI, Fredrickson DS: Estimation of the concentration of low density lipoprotein cholesterol in plasma, without use of preparative ultracentrifuge. Clin Chem 1972; 18:449-502.

24 Sievi E, Lahteenmaki TA, Alanko J, Vuorinen $\mathrm{P}$, Vapaatalo $\mathrm{H}$ : Nitric oxide a regulator of prostacyclin synthesis in cultured rat heart endothelial cells. Arzneimittelforschung 1997;47: 1093-1098.

25 Pigazzi A, Heydrick S, Folli F, Benoit S, Michelson A, Loscalzo J: Nitric oxide inhibits thrombin receptor-activating peptide-induced phosphoinositide 3-kinase activity in human platelets. J Biol Chem 1999;274:1436814375.

26 Murohara T, Scalia R, Lefer AM: Lysophosphatidylcholine promotes P-selectin expression in platelets and endothelial cells: Possible involvement of protein kinase $\mathrm{C}$ activation and its inhibition by nitric oxide donors. Circ Res 1996;78:780-789.

27 Riddell DR, Graham A, Owen JS: Apolipoprotein $\mathrm{E}$ inhibits platelet aggregation through the $L$-arginine:nitric oxide pathway: Implications for vascular disease. J Biol Chem 1997;272:89_ 95.

28 Anfossi G, Russo I, Massucco P, Mattiello L, Cavalot F, Tassone F, Perna P, Giori A, Trovati $\mathrm{M}$ : Platelet sensitivity to prostacyclin is reduced in obesity. Diabetologia 1998;41 (suppl 1):A328.
29 Anwaar I, Gottsater A, Wallmark A, Hedblad B, Lindgarde F, Mattiasson I: Intraplatelet cyclic $3^{\prime}, 5^{\prime}$ guanosine monophosphate is related to serum cholesterol. Int Angiol 1996;15:201206.

30 McDonagh PF, Hokama JY: Microvascular perfusion and transport in the diabetic heart. Microcirculation 2000;7:163-181.

31 Abbate R, Pinto S, Panetta A, Favilla S, Prisco D, Paniccia R, Vanni D, Gensini GF, Neri Serneri GG: Platelet synthesis of cyclooxygenase and lipoxygenase products in type I and type II diabetes. Prostaglandins Leukot Essent Fatty Acids 1988;31:9-15.

32 Butkus A, Shirey EK, Schumacher OP: Thromboxane biosynthesis in platelets of diabetic and coronary artery diseased patients. Artery 1982 ; 11:238-251.

33 Ruiz C, Alegria A, Barbera R, Farre R, Lagarda MJ: Lipid peroxidation and antioxidant enzyme activities in patients with type 1 diabetes mellitus. Scand J Clin Lab Invest 1999;59:99_ 105.

34 Mehta JL, Chen LY: Reversal by high-density lipoprotein of the effect of oxidized low-density lipoprotein on nitric oxide synthase protein expression in human platelets. J Lab Clin Med 1996;127:287-295.

35 Eynard AR, Tremoli E, Caruso D, Magni F, Sirtori CR, Galli G: Platelet formation of 12hydroxy-eicosatetraenoic acid and thromboxane B2 is increased in type IIA hypercholesterolaemic subjects. Atherosclerosis 1986;60:6166.

36 Schmidt K, Klatt P, Graier WF, Kostner GM, Kukovetz WR: High-density lipoprotein antagonizes the inhibitory effects of oxidized lowdensity lipoprotein and lysolecithin on soluble guanylyl cyclase. Biochem Biophys Res Commun 1992;182:302-308.

37 Oster O, Prellwitz W: Selenium and cardiovascular disease. Biol Trace Elem Res 1990;24:91103. 